\title{
Hour Times Picogram per Milliliter per Kilogram per Meter Squared
}

National Cancer Institute

\section{Source}

National Cancer Institute. Hour Times Picogram per Milliliter per Kilogram per Meter

Squared. NCI Thesaurus. Code C111228.

Hours times picograms per milliliter, divided by kilograms per meter squared. 